\title{
Current Issues and Future Trends in Sociology: Extending the Debate in Sociological Research Online
}

\author{
by Gayle Letherby \\ Coventry University \\ Sociological Research Online, Volume 10, Issue 1, \\ $<$ http://unw. socresonline.org.uk/10/1/letherby. $h t m />$ \\ doi:10.5153/sro. 1054
}

Received: 28 Jan 2005 Accepted: 1 Mar 2005 Published: 31 Mar 2005

\section{Introduction}

1.1 At the 2004 British Sociological Association (BSA) Annual General Meeting I presented a paper outlining some of the issues pertinent to a consideration of Current Issues and Future Trends in Sociology suggesting that recent and possible future developments both within the discipline and within higher education more generally are relevant both the health and future of the discipline of sociology and to the BSA. With the aim of stimulating both debate and activity in this area members of the BSA Executive Committee are, amongst other things, engaging in discussion with the wider membership of the association (e.g. through discussion with study group convenors and post-graduates); engaging in discussion with the ESRC about the health and future of the discipline, developing new and closer links with sister organisations such as the British Society of Criminology and the Social Policy Association and promoting and taking part in academic debate. The latter of these initiatives is demonstrated not least by the launch of this debate item in Sociological Research Online. This piece and the article - Sociology and Its Others:

Reflections on Disciplinary Specialisation and Fragmentation - by John Scott begin what we hope will be a stimulating debate focusing on the past, the present and the possible future of the discipline of sociology.

1.2 As John Scott argues, it is possible to frame Current Issues and Future Trends in Sociology as both negative and positive. Negative if we see the development of new specialisms and sub-disciplines as fragmentation but likely more positive if we identify these changes as growth and diversification. Negative if we dwell on the institutional changes that threaten departments and individuals and on the fact that the discipline is likely to lose a substantial proportion of researchers and teachers in the next ten years due to retirement but much more positive is if we reflect on the number of sociology jobs, including a number at professorial level, advertised in recent months in the pages of the Times Higher Educational Supplement and the Education Guardian. In addition the excellent TQA Teaching Assessment gradings for sociology and the comments of the RAE Panel 42 in 2001 all support a view that sociology is riding high.

1.3 As John Scott notes debates about what sociology is are nothing new, indeed have been characteristic of the discipline since the beginning. Furthermore, he is not the only past BSA president to reflection on this issue, as highlighted by Meg Stacey's BSA Golden Jubilee reflections:

The development of specialisms within sociology I initially viewed with considerable distrust. I say myself as a generalist, interested in looking at the interrelations of all aspects of society. Tradition and Change represented an attempt to do that. So the breaking up of sociology into specialisms made me anxious: would something precious be lost? Nevertheless, a highlight for me was the establishment of the Medical Sociology Group in 1969. (Margaret Stacey BSA President 1981 - 1983, Network 2001: 1).

1.4 The diversification of the discipline of sociology has material and economic significance as well as intellectual and academic implications. For example, within some institutions the introduction of criminology and/or cultural studies type courses in Social Science Faculties/Schools is part of the 'survival of sociology' agenda (i.e. an attempt to protect sociology jobs). However, there are dangers here in that the introduction of these courses, which are very popular with potential students, can lead to a decrease in student numbers on sociology courses. The current popularity of criminology and cultural studies is also reflected in the agenda of publishers. In addition we have recent real evidence of the impact of 'market force' concerns on Sociology departments in some universities and we know that many of our colleagues are teaching within and/or managing areas where sociology is only one discipline amongst many.

1.5 As an A Level student studying sociology the first non-text book I read was Coal is our Life: an analysis of a York shire mining community by Dennis and Henriques (1969). Right from the start sociology made me feel differently about the social world in which I lived and about my place within it. This, then, was the 
beginning of the development of my personal 'sociological imagination' (Mills 1970): a theoretically inquisitive approach relevant for all social scientists. Twenty-first century social science students are interested in the social world too but of course they have been affected by recent history and by debates over whether we live in a 'post-modern, post-feminist risk-society' or indeed whether there is such a thing as society at all. Contemporary students are also affected by the 'culture of celebrity/infamy' and the fact that 'celebrity represents success and achievement within the social world' (Marshall 1997:x) which perhaps explains why a colleague was recently told unashamedly by a first year student about the biography of David Beckham that they had just bought as their first academic purchase.

1.6 Problems associated with a changing student population and with the 'entrepreneurial trend' within higher education where the sector is increasingly 'forced' into redevelopment as a service industry (e.g. see Epstein 1995) do not affect sociology alone. Yet, it is sociology with its 'openness and flexible response to new opportunities' and its 'intellectual task [which] centres on the idea of what it is to talk about human 'society' in all its complexity' (Scott this edition) which is ideally placed to reflect on its own past, present and future and the past, present and future of higher education itself. This debate within the 'pages' of Sociological Research Online is part of this reflection.

\section{References}

DENNIS, N. and Henriques, F. (1969) Coal is Our Life: an analysis of a Yorkshire mining community London: Barnes and Noble.

EPSTEIN, D. (1995) In our (New) Right Minds: the hidden curriculum in the academy in L. Morley and V. Walsh (eds) Feminist Academics: creative agents for change Taylor and Francis: London.

MARSHALL, P. D. (1997) Celebrity and Power: fame in contemporary culture, Minneapolis: University of Minnesota Press.

MILLS, C. Wright (1970) The Sociological Imagination, Harmondsworth: Penguin.

And NETWORK: newsletter of the British Sociological Association No 80, October 2001: 1-2 'Peaks and Troughs in British Sociology (Sheila Allen, Meg Stacey, Martin Albrow, Bob Burgess, John Westergaard, David Morgan) 